\title{
Atypical Takotsubo syndrome
}

\author{
Andreia Fernandes, Joana Trigo, Paula Mota, António Leitão-Marques
}

Centro Hospitalar e Universitário de CoimbraHospital Geral, Coimbra, Portugal

\section{Correspondence to} Dr Andreia Fernandes, andreiafvf@gmail.com
To cite: Fernandes $A$, Trigo J, Mota P, et al. BMJ Case Rep Published online: [please include Day Month Year] doi:10.1136/bcr-2013009881

\section{DESCRIPTION}

A 52-year-old woman without cardiovascular risk factors was admitted with oppressive chest pain following an emotionally stressed situation. The ECG showed an ST segment elevation in leads V2-V3 and biphasic $\mathrm{T}$-wave in anteroseptal and lateral leads (DI, aVL, V1-V3) (figure 1A). Laboratory test revealed slightly elevated levels of Troponin I $(0.068 \mathrm{ng} / \mathrm{ml}(<0.012 \mathrm{ng} / \mathrm{ml}))$. Transthoracic echocardiography revealed akinesia of the midportion of the septum and free wall of the left ventricle (LV) and normal contractility of the basal and apical region with $68 \%$ ejection fraction. The left ventriculogram confirmed the akinesia with compensatory hyperypercontractility of the basal and apical segments (figure 1B). Cronary angiogram showed no coronary disease. She was discharged with carvedilol (3.125 mg/once daily), ramipril (1.25 mg/once daily), aspirin (100 mg/once daily) and atorvastatin $(10 \mathrm{mg} /$ once daily). The echocardiogram performed at discharge and follow-up (6 months) showed regression of the wall motion abnormalities.

In Takotsubo syndrome ('left ventricular apical ballooning syndrome' or 'broken-heart syndrome') the majority of reported cases involve the apical

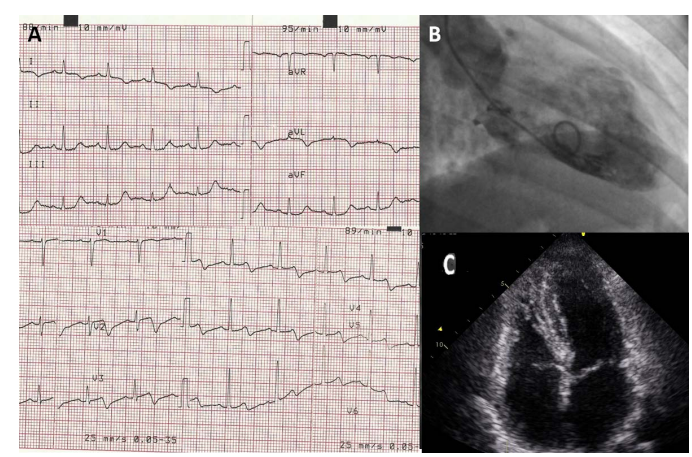

Figure 1 (A) 12-lead electrocardiogram showing an ST segment elevation in leads V2-V3 and biphasic T-wave in anteroseptal and lateral leads (DI, aVL, V1-V3). (B) Left ventricle angiogram with akinesia with compensatory hypercontractility of the basal and apical segments. (C) Follow-up echocardiogram without the wall motion abnormalities reported. region of the LV. Only a small number of atypical cases (new variants) have been described involving the midportion of the $\mathrm{LV}$ or the basal portion (inverted Takotsubo). ${ }^{1}$ As in classical forms symptoms and the ECG findings mimic myocardial infarction in patients without obstructive coronary artery disease. It is predominantly found in female patients. Emotional or physical stress is the common trigger.

The course is usually benign and reversible with total recovery of the ventricular function in most cases. ${ }^{2}$ Potential fatal complications like cardiogenic shock and lethal arrhythmias can occur in the acute phase.

\section{Learning points}

- Takotsubo syndrome is a differential diagnosis of acute myocardial infarction that occurs in the absence of coronary artery disease.

- It occurs mainly in middle-aged women in the context of stressful events and presents transient contractility changes.

- Despite the fact that the most cases involve the apical region of the left ventricle (preserving the more basal segments), sometimes variants with a more focal commitment may occur.

Contributors AF wrote the paper and AL-M reviewed it. JT preformed the echocardiogram and PM preformed the ventriculogram.

Competing interests None.

Patient consent Obtained.

Provenance and peer review Not commissioned; externally peer reviewed.

\section{REFERENCES}

1 Hurst RT, Askew JW, Reuss CS, et al. Transient midventricular ballooning syndrome: a new variant. J Am Coll Cardiol 2006:48:579-83

2 Kurowski V, Kaiser A, von Hof $\mathrm{K}$, et al. Apical and midventricular transient left ventricular dysfunction syndrome (Tako-Tsubo cardiomyopathy). Chest 2007;132:809-16 


\section{Images in...}

Copyright 2013 BMJ Publishing Group. All rights reserved. For permission to reuse any of this content visit http://group.bmj.com/group/rights-licensing/permissions.

BMJ Case Report Fellows may re-use this article for personal use and teaching without any further permission.

Become a Fellow of BMJ Case Reports today and you can:

- Submit as many cases as you like

- Enjoy fast sympathetic peer review and rapid publication of accepted articles

- Access all the published articles

- Re-use any of the published material for personal use and teaching without further permission

For information on Institutional Fellowships contact consortiasales@bmjgroup.com

Visit casereports.bmj.com for more articles like this and to become a Fellow 